Kumawula, Vol. 3, No.3, Desember 2020, Hal 449 - 456 DOI: https://doi.org/10.24198/kumawula.v3i3.28134

ISSN 2620-844X (online)

Tersedia online di http://jurnal.unpad.ac.id/kumawula/index

\title{
PELATIHAN KONSEP DIRI REMAJA PUTRI UNTUK MEMBANGUN PEMAHAMAN TENTANG STANDAR KECANTIKAN
}

\author{
Mahvira Putri Mahanani ${ }^{1}$, Dwi Laraswati ${ }^{2}$, Reva Salsadilla ${ }^{3}$, Hana Nabilah ${ }^{4}$, \\ Hery Wibowo ${ }^{5}$ \\ ${ }^{1}$ Mahasiswa Sosiologi, Fakultas Ilmu Sosial dan Ilmu Politik, Universitas Padjadjaran \\ ${ }^{2}$ Mahasiswa Sosiologi, Fakultas Ilmu Sosial dan Ilmu Politik, Universitas Padjadjaran \\ ${ }^{3}$ Mahasiswa Sosiologi, Fakultas Ilmu Sosial dan Ilmu Politik, Universitas Padjadjaran \\ ${ }^{4}$ Mahasiswa Sosiologi, Fakultas Ilmu Sosial dan Ilmu Politik, Universitas Padjadjaran \\ ${ }^{5 *}$ Departemen Kesejahteraan Sosial, Fakultas Ilmu Sosial dan Ilmu Politik, Universitas Padjadjaran \\ *Korespondensi : hery.wibowo@unpad.ac.id
}

\begin{abstract}
ABSTRAK
Standar kecantikan merupakan fenomena yang dikonstruksikan secara sosial di masyarakat. Dari masa kemasa standarisasi tentang kecantikan ini selalu berubah dan membaut orang sulit untuk mendefinisikan standar cantik itu sendiri, Berdasarkan hal tersebut, masih banyak masyarakat yang masih bingung atau ragu maupun rancu dengan standar ini. Kebingungan ini, khususnya terjadi pada remaja putri yang masih membangun konsep dirinya. Ketidaksiapan konsep diri indivdu atas sebuah standar kecantikan dapat berakibat pada ketidakpercayaan diri, sehingga diperlukan kiranya sebuah program yang dapat membantu remaja putri agar dapat membangun kepercayaan dirinya atas standar kecantikan yang dimiliki setiap masing-masing orang.

Program pengabdian masyarakat ini menggunakan bentuk aktivitas pelatihan yang bertujuan untuk membangun konsepsi yagn baik tentang beauty standard serta pentingnya konsep diri yang baik atas insecurity di setiap individu. Metode action research ini diaktualisasikan melalui webinar di platform Whatsapp group dengan 80an orang peserta yang mayoritas remaja perempuan. Pelaksanaan webinar ini, menghasilkan sejumlah manfaat bagi peserta, hal ini terlihat dari tanggapan peserta yang menyatakan bahwa dirinya menjadi lebih paham dan percaya diri dengan tampilannya sendiri karena peserta telah memahami bahwa tidak ada standar kecantikan yang baku, dan definisi dari sebuah kecantikan bersifat subjektif. Kecantikan tidak serta merta penampilan fisik saja namun ada hal lain yang menjadikan seorang individu menjadi menarik bagi orang lain baik itu karena kepribadian, kebiasaan, maupun perilaku.
\end{abstract}

Kata Kunci : Konsep Diri, Standar Kecantikan, Rasa Tidak Percaya Diri, dan Konstruksi Sosial

\begin{abstract}
Beauty standards are a phenomenon that is socially constructed in society. The beauty standards has been evolving and forming a diverse perspective of beauty. Based on that case, there are a lot of people who are still trapped in a misconception about the beauty standard. The misconception about the beauty standard mainly occurs in teenagers that still has an unstable self-concept. The unstable self concept of a teenager can be one of the factors of bad self-confidence so that the role of education is needed in educating people about the self-concept and beauty standard. So that one of the ways to educate people about self-concept and beauty standards is through seminars or training. The training of self-concept in a teenager and beauty standards used an action research method that is proposed to give insights about the beauty standard and the importance of self-concept against insecurity. The action research method was implemented through a webinar in a WhatsApp group platform with more than 80 female teenagers participating as the majority. The seminar was useful for the participant as they give some testimonials that they feel more confident with their selves no matter how they look because they have understood that there is no exact beauty standard and the beauty definition is subjective. Beauty is not only defined as physical appearance but there are many things that can defines a beauty either personality, habits or attitude.
\end{abstract}

Keywords: self-concept, beauty standard, insecurity, social construction. 


\section{PENDAHULUAN}

Pada Era Revolusi Industri 4.0 ini manusia yang mengalami sebuah perubahan yang fundamental yang mana sangat berbeda dengan kehidupan manusia sebelumnya. Menurut Schwab, dalam Susanti Ernita (2019:49) menyatakan bahwa: "Era Industri 4.0 adalah istilah yang digunakan untuk merujuk pada era dimana terjadi perpaduan teknologi yang mengakibatkan dimensi fisik, biologis, dan digital membentuk suatu perpaduan yang sulit untuk dibedakan”. Perkembangan era revolusi industri 4.0 ini terus memengaruhi gaya hidup seseorang yang mana salah satunya adalah pada pengaruh kecantikan seseorang saat ini. Perkembangan teknologi terus berevolusi yang membuat dunia kecantikan dan estetika ikut serta terseret arus transformasi. Namun setiap insan manusia berhak mendefinisikan bagaimana cantik itu sendiri, karena sejatinya setiap orang mendefinisikan kata cantik itu berbeda-beda. Sudah tidak ada yang mampu untuk mendefinisikan standar kecantikan itu secara jelas. Definisi cantik tergantung pada berbagai persepsi yang kian berganti dengan seiring berkembangnya zaman. Fenomena ini semakin kuat mengingat dunia juga telah memasuki era esteem economy (Kasali, 2018).

Beauty standard 4.0 kini bertambah dengan adanya pengaruh teknologi dan media sosial. Perkembangan teknologi dan media sosial merupakan hal yang menyebabkan semakin bergesernya beauty standard pada hari era masyarakat 4.0 ini. Para individu yang mengakses media sosial dapat dengan mudah melakukan berbagai kegiatan seperti berkomunikasi, mengunggah foto dan video, maupun memberikan komentar atas suatu hal (Nasution, Jati, \& Setia, 2019). Media sosial kemudian juga menjadi tempat untuk eksistensi dan aktualisasi diri bagi tiap individu karena melalui media sosial, penampilan seseorang akan mendapat penilaian bisa berupa pujian, sindiran, bahkan hujatan. Hal tersebut yang menjadikan tuntutan baru dalam dunia estetika. Opini publik menjadi sedemikian penting, eksistensi menjadi tujuan untuk mempercantik diri, bukan lagi berpegang pada sudut pandang dokter dengan golden ratio, tidak lagi merujuk kepada keinginan pribadi. Dokter Lanny mengungkapkan bahwa pasien yang berdatangan mengatakan bahwasanya mereka menginginkan kecantikan dari netizen dalam media sosial (CNNIndonesia.com, 2019).

Persepsi masyarakat mengenai cantik terbatas hanya pada penampilan fisik saja seperti, memiliki kulit yang putih dan bersih. Sebagaimana disebutkan oleh Worotitjan (2014), pembentukan standar kecantikan merupakan dampak dari budaya patriarki yang sudah diwariskan dari generasi ke generasi. Pengaktualan standar kecantikan terbagi menjadi 2 (dua) unsur yaitu kecantikan yang dilihat dari luar (fisik), dan kecantikan dari dalam (batiniah). Meningkatnya penggambaran dan internalisasi perempuan akan kecantikan dan bagaimana mereka mendapatkan bentuk tubuh dan wajah seperti yang terpampang dalam media ini menjelaskan bagaimana media massa berpengaruh terhadap cara maupun aturan seseorang dalam berpenampilan (Polivy dan Herman, 2004).

Hal yang tergambar dalam media dapat berbahaya karena dapat meremehkan hal yang dianggap orang sebagai normal atas ciri khas masyarakat tertentu. Penelitian menjelaskan bahwa perempuan pada dasarnya memiliki keinginan bagi tubuh mereka agar tampak melalui cara tertentu yang bergantung pada; apa yang menurut mereka menarik bagi orang lain dan seperti apa orang lain pada umumnya menurut mereka. Perempuan dikatakan cantik tidak hanya dari wajahnya, tetapi juga berkaitan dengan kulit yang putih dan mulus (Kasiyan, 2008: 281), yang mana hal ini akan membuat perempuan melakukan apa saja agar dianggap cantik oleh lingkungannya. Dalam Penelitian terdahulu yang berjudul "Konsep Diri Pada Konsumen Klinik Kecantikan” yang ditulis oleh Riris Anggraini pada tahun 2017 menyebutkan, bahwa terdapat fakta yang mengatakan bahwa konsep diri yang bersifat negatif mampu mengantarkan pada ketidakpercayaan diri pada pengunjung klinik kecantikan yang mana mereka tidak merasa 
puas akan penampilan dirinya dan menilai rendah dirinya, maka dari itu mereka memutuskan untuk melakukan treatment di klinik kecantikan. Song dan Hattie (Dalam Hurlock, 2008) mengatakan bahwa konsep diri seseorang dapat dilihat dari penampilan dirinya yang terbentuk atas interaksi dan pengalaman.

Masa remaja merupakan periode yang sangat berpengaruh dalam kehidupan seseorang di mana seorang individu berada di ambang perbatasan antara masa anak-anak dan dewasa sehingga terdapat beberapa tahap yang dilewati seorang remaja seperti masa peralihan atau transisi, masa perubahan, masa timbulnya permasalahan, masa pencarian identitas diri, usia yang menakutkan, masa unrealism, hingga masa pendewasaan diri (Krori, 2011; Santoso dan Lestari, 2019). Permasalahan dalam melihat citra tubuh yang negatif membuat remaja putri mengalami gangguan yang sering terjadi adalah ketidakpuasan diri, gangguan kepercayaan diri hingga berujung pada depresi. Gangguan tersebut membuat seseorang merasa cemas dengan kekurangan fisik minor maupun kekurangan imajiner dirinya. Penilaian individu terhadap dirinya sendiri termasuk kedalam selfconcept atau konsep diri. Menurut Calhoun dan Acocella (1995) terdapat tiga komponen penting didalam konsep diri seseorang yakni pengetahuan tentang dirinya sendiri, harapan dan penilaian diri individu dari perspektif orang lain. Pengetahuan individu atas dirinya sendiri dapat dikatakan sebagai segala hal yang individu gambarkan tentang seluruh kenyataan yang dimiliki oleh individu terkait dengan yang ada di dalam dirinya. Harapan atau ideal self merupakan ekspektasi individu terhadap dirinya sedangkan, penilaian dari individu lain adalah salah satu bentuk respon atau interpretasi orang lain tentang diri seseorang.

Persepsi akan standar kecantikan ini membuat remaja putri tak dapat lagi berdiri pada kakinya sendiri dan tanpa disadari orangorang hidup pada standarisasi yang diciptakan oleh sistem kapitalis menggunakan media massa sebagai salah satu bentuk usaha dalam mengonstruksikan standar kecantikan tertentu bagi perempuan. Menurut Yan Yan (2014), fenomena industri media massa yang menyoroti bentuk ciri fisik tertentu yang secara tidak langsung mengonstruksikan standar kecantikan merupakan hal yang sudah sangat umum terjadi di negara barat dan secara perlahan menjadi mengglobal. Media massa yang menampilkan model dengan ciri fisik tertentu di dalam konten kecantikannya secara tidak langsung membangun standar kecantikan dan mencoba memengaruhi perspektif semua wanita tentang arti sebuah tampilan fisik yang indah. Sistem ini sengaja menciptakan perempuan menjadi satu dominasi. Waktu dan uangnya disiapkan untuk dapat mencapai target standar kecantikan yang dikatakan sempurna itu, padahal kenyataannya adalah mereka telah masuk ke dalam jeratan kapitalis. Perempuan tereksploitasi tidak lagi dengan cara-cara kuno, tetapi dengan cara yang lebih halus dengan membodohi perempuan melalui berbagai macam produk-produk yang kapitalisme jajakan.

Maka penting kiranya dilakukan kajian yang lebih mendalam berkaitan dengan self concept atas beauty standard dan insecurity mengingat self-concept adalah salah satu hal penting di dalam diri setiap individu yang menjadi dasar gambaran individu terhadap dirinya sendiri. Apabila seseorang tidak memiliki konsep diri yang baik dan lebih terpengaruh banyak hal eksternal yang negatif, maka akan berisiko buruk bagi diri individu itu sendiri terlebih berkaitan dengan perasaan insecurity atau ketidakpercayaan diri.

\section{METODE PENGABDIAN MASYARAKAT}

Metode pengabdian masyarakat yang dilakukan adalah dengan metode pelatihan. Pelatihan (Lall \& Sharma, 2009) merupakan konsep tentang akuisisi (penambahan) pengetahuan, keterampilan dan kemampuan melalui program pengembangan professional. Pelatihan yang dilakukan bertujuan untuk mengkaji intervensi khusus berbasis kerangka teoritis yang ditentukan sebelumnya yaitu dengan menggunakan teori sosiologi konstruksi sosial yang dikemukakan oleh Peter L. Berger dan Thomas Luckmann. Davison, Martinsons \& Kock (2004) 


\section{TINJAUAN PUSTAKA}

\section{Self-Concept}

Self-Concept ialah bagaimana cara pandang seseorang untuk mendeskripsikan dirinya sendiri, hal ini bisa dilihat dari berbagai kelebihan dan kekurangan yang dimiliki. Selfconcept ini bukan semata-mata hal yang sudah ada dalam dirinya sejak lama bahkan sejak lahir telah terbangun. Namun, yang dimaksud dengan self-concept di sini adalah di mana seseorang tersebut menilai dirinya sendiri dan juga pandangan yang diberikan oleh orang lain. Seseorang yang memiliki konsep diri positif, berani mencoba dan tidak takut akan risiko, percaya diri, selalu optimis dan tidak pesimis, serta memiliki semangat untuk menata arah hidupnya (Gunawan, 2005). Menurut Seifert dan Hoffnung (Desmita, 2010: 163) selfconcept adalah suatu pemahaman mengenai diri atau ide tentang diri sendiri. Self concept merupakan landasan untuk dapat menyesuaikan diri dan terbentuk karena suatu proses umpan balik dari individu yang lain.

\section{Beauty Standard}

Menurut Carolina (2015) standar kecantikan yang terdapat di berbagai negara itu berbeda-beda. Faktor pembedanya adalah adat istiadat, kebudayaan, kepercayaan hingga peranan media massa yang menjadi sumber informasi termasuk salah satunya yakni beragam informasi yang memuat unsur-unsur beauty standard. Menurut Yan Yan (2014), industri media massa baik media cetak maupun elektronik memuat konten-konten yang menunjukan nilai standar kecantikan, hal tersebut tidak hanya terjadi di negara-negara tertentu saja, namun secara global media massa terkadang memuat konten-konten dengan standar kecantikan tertentu. Contohnya adalah majalah Cosmopolitan yang merupakan salah satu majalah wanita terbesar di dunia yang telah tersebar luas dalam 36 bahasa dan memiliki 63 edisi internasional. Dari adanya konten-konten tertentu yang memuat nilai-nilai standar kecantikan maka dapat secara signifikan mempengaruhi masyarakat dalam pembentukan persepsi atau mindset tentang standar kecantikan. Maka dari itu, media massa memiliki peran sebagai wadah untuk memperkenalkan atau mensosialisasikan nilainilai tertentu yang dapat berdampak signifikan terhadap masyarakat.

Walaupun secara global, media telah menyuguhkan berbagai konten yang berkaitan dengan beauty standard, namun kecantikan masih tetap menjadi hal yang subjektif dimana standar kecantikan setiap orang itu pasti berbeda-beda. Standar kecantikan yang umum berkembang di masyarakat ialah cantik itu harus putih, tinggi, langsing, dan sebagainya. Padahal pada faktanya, terdapat banyak sekali standar kecantikan yang beragam di berbagai penjuru dunia.

\section{Insecurity}

Insecurity adalah salah satu topik yang sangat hangat dibicarakan akhir-akhir ini, umumnya bagi para remaja. Insecurity ini menjadi salah satu perilaku yang ada di dalam dirinya. Insecurity sendiri adalah salah satu jenis perilaku atau perasaan seseorang di mana seseorang tersebut berada pada posisi tidak nyaman, tidak aman, tidak memiliki rasa percaya diri, memiliki rasa takut akan sesuatu yang dilakukan maka dari itu timbul ketidakpuasan dan ketidakyakinan atas kapasitas yang ada di dalam dirinya. Perasaan atau perilaku insecurity ini biasanya memicu seseorang untuk bersembunyi dan memupuk dirinya agar orang lain tidak mengetahui kekurangan dalam diri seseorang tersebut.

\section{Teori Konstruksi Sosial Berger dan Luckmann}

Teori Konstruksi Sosial merupakan proses pemaknaan yang dilakukan oleh setiap individu terhadap lingkungannya serta aspek yang berada di luar dirinya, yaitu makna subjektif yang berasal dari realita objektif dalam kesadaran setiap individu dalam menjalani aktivitasnya sehari-hari. Berger menafsirkan suatu realitas sosial sebagai suatu hal yang kemunculannya tidak bergantung pada tiap-tiap individu. Dalam karya Berger bersama Luckmann, Berger menguraikan bahwa dalam analisis sosiolog hal yang terpenting adalah realitas kehidupan sehari-hari, yaitu realitas yang dialami atau dihadapi setiap individu. 
Berger (dalam Rosidah 2011:18) menyebutkan 3 (tiga) proses dalam teori konstruksi sosial yaitu eksternalisasi, objektivasi, dan internalisasi. Eksternalisasi adalah proses adaptasi diri dengan dunia sosio-kultural sebagai komoditas manusia. Lalu, objektivasi merupakan hasil yang sudah dicapai baik fisik maupun mental dari proses sebelumnya yaitu eksternalisasi. Sedangkan, internalisasi adalah suatu proses penyerapan kembali dunia objektif dalam kesadaran hingga subjektif individu dipengaruhi oleh struktur dunia sosial. Teori konstruksi sosial Berger dan Luckmann menempatkan kajiannya terhadap hubungan konteks sosial dimana suatu pemikiran timbul dengan pemikiran manusia.

\section{HASIL DAN PEMBAHASAN}

Berangkat dari keresahan mengenai insecure pada perempuan tentang penampilannya yang tidak memenuhi standar kecantikan yang dikonstruksikan di dalam masyarakat, penulis tergerak melakukan seminar untuk memperkenalkan konsep-konsep bagaimana beauty standard itu terbentuk hingga bagaimana cara membentuk konsep diri yang positif. Dari sana penulis mencoba menyadarkan para perempuan untuk tidak lagi insecure dengan membangun kekurangan yang ada dengan positif.

Seminar ini dilakukan secara online melalui Whatsapp karena melihat situasi kondisi yang tidak memungkinkan untuk berkumpul akibat virus corona yang sedang menyebar ini. Whatsapp tidak hanya untuk komunikasi antar personal namun mulai digunakan untuk media seminar online melalui Whatsapp group. Seminar daring ini dilaksanakan pada hari Minggu, 5 April 2020 pukul 19.30 WIB, dengan jumlah peserta 80 orang yang terdiri dari mahasiswa dan SMA. Peserta yang mengikuti acara ini tersebar dari beberapa daerah diantaranya, Cirebon, Garut, Bogor, Cianjur, Pangandaran, Tasikmalaya, Ciamis, Bandung, Banjar, Tanggerang Selatan, dan Gunungkidul Yogyakarta.

Walaupun seminar daring yang dilaksanakan melalui media WhatsApp ini dinilai lebih praktis dan dapat diakses dengan mudah oleh banyak orang namun ada beberapa kekurangan dan kelebihannya tersendiri. Adapun hasil pelaksanaan dan pembahasan mengenai seminar daring tersebut dapat diuraikan sebagai berikut:

\section{- Hasil}

Hasil dari seminar daring menggunakan metode action research dalam rangka mengedukasi remaja putri tentang konsep diri yang berkaitan dengan insecurity dan standar kecantikan ini dinilai telah cukup memuaskan. Sebagian besar peserta sudah paham bahwa cantik bukan semata-mata dilihat dari fisik, tetapi dilihat dari attitude, dan kepribadian seseorang. Definisi cantik itu relatif, yang mana beda orang pasti berbeda juga sudut pandangnya terhadap makna cantik itu sendiri. Materi seminar yang disampaikan melalui media pesan suara atau voice note dan konten pendukung berupa gambar membantu para peserta untuk memahami materi yang dijelaskan oleh pembicara. Selain itu, pemahaman peserta tentang materi yang sudah disampaikan juga dapat diukur dari keaktifan peserta dalam sesi diskusi yang mana pada sesi diskusi ini para peserta tidak hanya memberikan pertanyaan tetapi juga memberikan tanggapan dan argumentasi mengenai topik yang dibahas. Bahkan, pada saat sesi diskusi para peserta memberikan tanggapan berupa pengembangan opini dari topik utama yang mana hal ini menunjukan bahwa selain memahami topik yang disampaikan pembicara, peserta juga mendapatkan hal baru yang membuka pemikirannya tentang konsep diri dan standar kecantikan. Beberapa peserta menghubungkan fenomena standar kecantikan ini dengan beberapa isu kesehatan serta adapun peserta lain yang mengaitkannya dengan konsep diri ideal.

\section{- Pembahasan}

Walaupun seminar daring ini telah cukup memuaskan dengan adanya keaktifan dari peserta dalam sesi diskusi, namun terdapat 
beberapa evaluasi yakni waktu seminar yang tidak sesuai jadwal. Seminar daring yang dilaksanakan mulai dari pukul 19.30 dan diharapkan selesai pada pukul $20.30 \mathrm{ini}$ berakhir pada 21.30. Walaupun seminar dimulai tepat waktu namun ternyata pada waktu diskusi pembicara atau narasumber membutuhkan waktu yang lebih lama dari jadwal untuk menanggapi beberapa pertanyaan dari peserta, selain itu adanya sesi diskusi antar peserta menambah alokasi waktu yang ada sehingga hal tersebut berdampak pada acara yang berakhir tidak sesuai dengan jadwal. Adapun pelaksanaan seminar daring tersebut dimulai dengan cara memantik audiens atau peserta dengan sebuah pertanyaan mengenai "Cantik Itu Seperti Apa?”. Melalui pertanyaan tersebut penulis ingin mengetahui pandangan cantik menurut peserta seminar dan hasilnya opini tentang cantik menurut para peserta sangat beragam. Setelah mengetahui opini tersebut pembicara menjelaskan tentang adanya fenomena standar kecantikan di masyarakat melalui berbagai perspektif dan konstruksi sosial dalam sesi ini pembicara menjelaskan bahwa cantik itu relatif dan tidak ada standar kecantikan tertentu. Kemudian, pembicara melanjutkan sesi pematerian dengan pemaparan materi tentang konsep diri dan insecurity. pada setiap sesi pematerian para peserta diminta untuk menyimak dan dihimbau untuk tidak mengirimkan pesan di grup selama sesi ini moderator mematikan fitur chat group bagi peserta agar semua peserta dapat menyimak dan kondusif. Setelah pematerian selesai peserta dipersilahkan untuk memberikan pertanyaan, hanya ada tiga pertanyaan terpilih di setiap terminnya. Kemudian, dilanjutkan dengan diskusi terbuka antar pembicara dan peserta, pada diskusi terbuka ini peserta bebas mengemukakan pendapatnya mengenai topik yang telah dibahas. Walaupun penulis sadari bahwa ada beberapa peserta yang tidak sempat mengikuti keseluruhan sesi seminar, namun penulis menyediakan notulensi bagi para peserta berkaitan dengan materi dan bahasan pada seminar daring tersebut.

Lalu, jika dikaitkan dengan Teori Konstruksi Sosial yang dikemukakan oleh Peter L. Berger maka, dalam tahapan Eksternalisasi, peran terbesar peserta seminar daring mengkonstruksikan makna “cantik” adalah keluarga, dimana keluarga merupakan lingkungan pertama yang dijalani seseorang semasa hidup di dunia. Keluarga merupakan tempat dimana kita belajar pertama kali dan dari tahapan ini kemudian para peserta seminar khususnya memaknai kata "cantik". Tahapan selanjutnya ialah Objektivasi, dimana melalui tahap ini pemaknaan "cantik" peserta seminar daring mulai dipengaruhi dan dibentuk oleh lingkungan luarnya, tak hanya oleh pertemanan atau pergaulan tetapi juga ada faktor lain seperti media sosial, iklan, serta pengaruh dari beauty vlogger, sehingga terbentuk suatu realitas subjektif yang berbeda dari apa yang mereka pandang atau pikirkan sebelumnya. Tahap terakhir ialah Internalisasi, dimana setelah melewati 2 tahapan sebelumnya para peserta seminar daring telah memahami pemaknaan "cantik" yang sesungguhnya, sehingga terciptalah konstruksi baru. Melalui seminar daring ini para peserta yang mana mayoritas adalah perempuan menjadi lebih terbuka pemikirannya dan menyadari bahwa cantik itu relatif, semua perempuan itu terlahir cantik, sebagian peserta seminar daring sudah ada yang memahami bahwa cantik tak hanya persoalan fisik saja, tetapi kecantikan yang terpancar dari dalam dirilah yang lebih abadi.

\section{KESIMPULAN}

Proses pelatihan dilaksanakan dengan semangat dan target memberikan edukasi yang bermanfaat. Sesi pelatihan ini diisi dengan materi tentang fenomena standar kecantikan, dan juga konstruksi sosial yang melingkupinya. Selanjutnya upaya membangun pemahaman tentang bagaimana makna cantik yang 
Sesungguhnya bagi remaja putri pada khususnya dan kaum wanita pada umumnya.

\section{SARAN DAN REKOMENDASI}

Adapun saran rekomendasi yang diberikan untuk pelaksanaan program pengbadian masyarakat yang lebih baik adalah:

1. Sebelum melakukan program pengabdian masyarakat yang berbentuk pelatihan, sangat perlu dipertimbangkan untuk melakukan proses assessment (atau pengenalan lebih dalam terkait kondisi peserta)

2. Perbanyak konten menarik yang dapat memantik impresi dari peserta untuk menyimak materi yang disampaikan.

3. Sebagai alat ukur pemahaman peserta, dapat dilakukan test sebelum dan sesudah pemaparan materi dilakukan sehingga dapat diukur tingkat kemampuan peserta berkaitan dengan topik atau materi yang disampaikan.

\section{DAFTAR PUSTAKA}

Dzulkarnain, D. R. (2016). KONSTRUKSI KECANTIKAN DI KALANGAN WANITA KARIER (DI KECAMATAN LAMONGAN, KABUPATEN LAMONGAN). Jurnal Universitas Trunojoyo Madura, 1-16.

Kasali, R. (2018). The Great Shifting. Jakarta: Penerbit Gramedia Pustaka Utama.

Lall, M., \& Sharma, S. (2009). Personal Growth and Traning Development. New Delhi: Excel Book.

Raditya, O. N. (2013). KONSTRUKSI "PEREMPUAN CANTIK" DI KALANGAN SISWI SMAN 1 SOOKO MOJOKERTO. Jurnal Universitas Negeri Surabaya, 1-7.

Raharjo, R. S. (2019). Pola Asuh Orangtua dan Konsep Diri Anak Didik LPKA Bandung. Jurnal Pekerjaan Sosial Unpad, 1-13.

Santoso, M. A. (2019). Pelaksanaan Assertiveness Training Pada Anak
Berhadapan Dengan Hukum (ABH) di LPKA Bandung. Jurnal Pengabdian Kepada Masyarakat: Kumawula, 1-13.

Anggraini, R. (2017). Konsep Diri Pada Konsumen Klinik Kecantikan. Jurnal UMS, 1-19.

Casmini. (2015). Implikasi Pemaknaan "Cantik" Terhadap Pelaksanaan Tata Tertib Mahasiswa. Jurnal UIN Sunan Kalijaga, 1-19.

Puput Tripeni. J. (2019, Februari 22). Dilema Beaty 4.0, saat Standar Cantik Ada di Tangan Netizen. Retrieved from CNN Indonesia: m.cnnindonesia.com

Megenal Beauty 4.0: Tren kecantikan Yang Ikuti Revolusi Industri 4.0. Retrieved from IDN TIMES: $\underline{\text { www.idntimes.com }}$

Handoyo, F. M. (2015). Konstruksi Sosial Masyarakat Terhadap Penderita Kusta. Jurnal Mahasiswa UNESA, 1-7.

Meisianti, D. (2020). Upaya Peningkatan Kompetensi Guru Vokasi Bidang Kecantikan Industri 4.0. EJournal, 6972.

Mu'awwanah, U. (2017). Perilaku Insecure Pada Anak Usia Dini. Jurnal UIN Banten, 1-12.

Murdjito, G. (2012). Metode Penelitian Pengabdian pada Masyarakat. Slideshare, 1-5.

Nasution, Z., Jati, A. K. N., \& Setia, S. (2019). PELATIHAN ETIKA BERBAHASA BAGI SISWA UNTUK MENINGKATKAN KETERAMPILAN BERKOMUNIKASI DI MEDIA SOSIAL. Kumawula: Jurnal Pengabdian Kepada Masyarakat, 2(2).

Sukardani, A. B. (2018). Representasi Konsep Kecantikan Perempuan di Era Millenials Melalui Beauty Influencer pada Media Sosial Instagram. Jurnal Universitas Negeri Surabaya, 1-4.

Sumartini, T. S. (2015). Mengembangkan Self Concept Siswa Melalui Model Pembelajaran Concept Attainment. Jurnal Pendidikan Matematika, 48-57. 
Wolf, N. (1990). The Beauty Myth: How Images of Beauty Are Used Against Women. New York: HarperCollins Publishers.

Worotitjan, H. G. (2014). Konstruksi Kecantikan Dalam Iklan Kosmetik Wardah. Jurnal E-Komunikasi, 1-10.

Yan Yan, K. B. (2014). The Globalization of Beauty: How is Ideal Beauty Influenced by Globally Published Fashion and Beauty Magazines?. Journal of Intercultural Communication Research, 194-214.

Yaumi, Muhammad \& Damopoli, Muljono. 2014. Action Research: Teori, Model dan Aplikasi Penerbit Kencana Prenadamedia Group. 